blood pressure later is not known, but circumstantial evidence in man and direct evidence in some animals suggest that it may. ${ }^{1}$ We think that the high intake of salt, as well as other aspects of the diet of young children in the United Kingdom, should be a cause for concern and further research.

This study was part of a paediatric project on the paediatric firm, and we gratefully acknowledge the help of Dr David Murdoch and Dr Michael Latter.

1 MacGregor GA. Sodium is more important than calcium in essential hypertension. Hypertension 1985;7:628-40.

2 Knudsen KD, Dahl LK. Essential hypertension: inborn error of sodium metabolism. Postgrad Med J $1966 ; 42: 148-52$.

3 Hofman A, Hazebroek A, Valkenburg HA. A randomized trial of sodium intake and blood pressure in newborn infants. FAMA 1983;250:370-3.

Accepted 28 February 1986

Charing Cross and Westminster Medical School, London W6 8RF

SALLY DE COURCY, MB, BS, house surgeon

HILARY MITCHELL, MB, BS, house surgeon

DAVID SIMMONS, BA, MB, house physician

GRAHAM A MACGREGOR, FRCP, senior lecturer and honorary consultant physician

Correspondence to: Dr G A MacGregor, Blood Pressure Unit, Department of Medicine, Charing Cross and Westminster Medical School, London W6 8RF.

\section{Acute non-A non-B hepatitis after typhoid fever}

Ten years after its initial description non-A non-B hepatitis remains a diagnosis of exclusion. Nevertheless, non-A non-B hepatitis includes infections of the liver caused by at least three viruses provisionally designated "blood transmitted," "coagulation factor transmitted," and "epidemic waterborne." Furthermore, there is some evidence of an association between shellfish consumption and some cases of non-A non-B hepatitis, ${ }^{23}$ and it has been suggested that these cases reported in Western countries may be sporadic cases of epidemic waterborne non- $A$ non- $B$ hepatitis, ${ }^{1}$ a hypothesis supported by an analysis of the clinical and biochemical features in 20 cases. ${ }^{4}$ Here we describe two patients admitted to our infectious diseases clinic for typhoid fever who then developed acute non-A non-B hepatitis.

\section{Case 1}

A 25 year old man experienced an abrupt onset of fever $\left(39^{\circ} \mathrm{C}\right)$, headache, and malaise. He was given acetylsalicylic acid ( $500 \mathrm{mg}$ every 4 hours). Five days later, because of persisting fever, constipation, abdominal pain, and discomfort, he was admitted to hospital. Because of a history of shellfish consumption 15 days before the onset of symptoms blood and stool cultures were performed and Widal reaction was tested. Salmonella typhi was isolated from the blood, and an increased titre of 0 agglutinins was recorded during the second week of illness. Chloramphenicol was started and continued according to the standard therapeutic regimen.

Routine alanine aminotransferase determinations showed a nineteenfold increase over the normal values during the second week of illness (four weeks after shellfish consumption), but without any symptoms. Acute non-A non-B hepatitis was diagnosed by exclusion: he was negative for hepatitis B surface antigen, IgM antibody to hepatitis B core antigen, cytomegalovirus, antihepatitis A virus, and heterophile antibody to Epstein-Barr virus. In particular, the assay for $\operatorname{IgM}$ anti-hepatitis A virus was repeatedly negative. HBsAg and IgM anti-hepatitis $\mathrm{A}$ were assayed by Abbott radioimmunoassays, IgM anti-core antigen by enzyme linked immunosorbent assay Corzyme-M (Abbott), IgM anticytomegalovirus by Enzygnost-Cytomegalie (Behringwerke), and antibodies to Epstein-Barr virus by Monosticon (Organon).

The patient recovered completely from both typhoid fever and non- $\mathrm{A}$ non-B hepatitis: his serum transaminase activity returned to normal within five weeks and remained normal for more than six months (figure).

\section{Case 2}

A 23 year old man was admitted to hospital with a one week history of high fever $\left(40^{\circ} \mathrm{C}\right)$, continuous headache confined to the frontal region, and constipation followed by diarrhoea. He had eaten oysters and mussels 10 days before the onset of symptoms. Salmonella typhi was isolated from stools, and treatment with chloramphenicol was started.
At the end of the fourth week of illness (five weeks after shellfish ingestion) there was a sharp rise in his serum transaminase activity with a decrease of prothrombin activity ( $<70 \%$ of normal). The patient was symptom free and anicteric. In this case too acute non-A non-B hepatitis was diagnosed by exclusion. The hepatitis ran an uneventful course with liver function values returning to normal and remaining so over 12 months after the onset of the disease.

\section{Comment}

Typhoid fever occurs sporadically in Italy, and shellfish ingestion is often responsible. Occasionally it is associated with acute hepatitis $A$, which is primarily transmitted by the faecal-oral route. Although faecal-oral non-A non-B hepatitis has been suggested to occur in some patients with biphasic hepatitis A, we are not aware of reports of non-A non-B hepatitis in patients with other stool borne transmitted diseases.

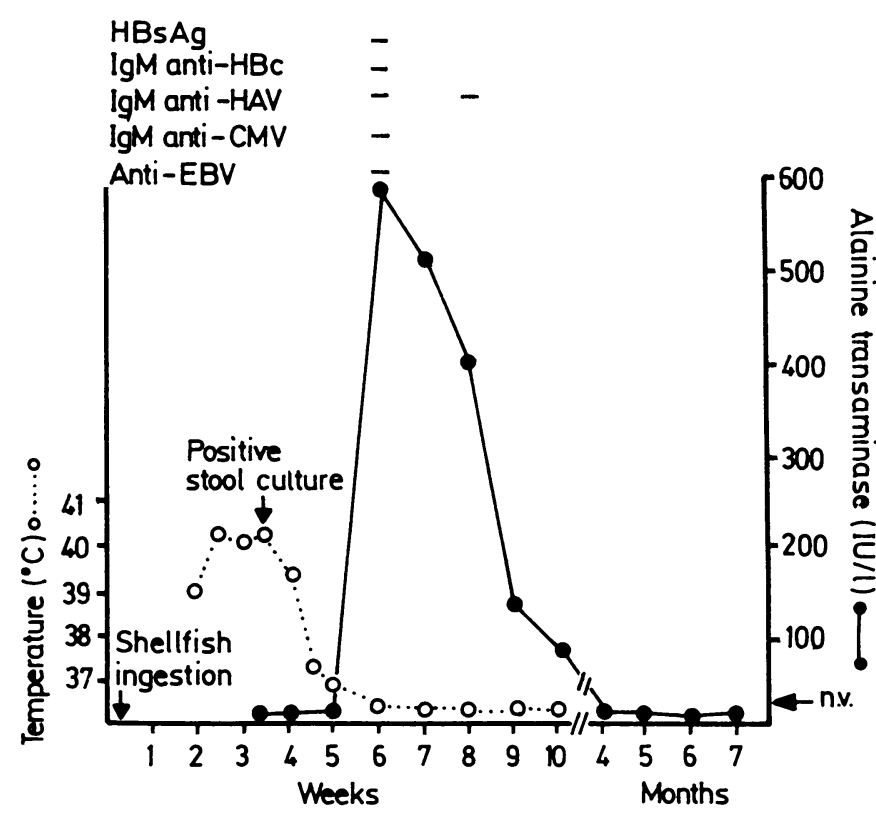

Case 1. Non-A non-B hepatitis after typhoid fever.

The observation of two cases of non-A non-B hepatitis after typhoid fever is intriguing. Although there is no direct evidence that the source of Salmonella typhi and non-A non-B virus was the same, the absence in these patients of a history of blood transfusion or admission to hospital within the preceding six months or a history of drug addiction or any other possible parenteral exposure suggests that food contaminated with human excreta might have been the source. In Western countries non-A non-B hepatitis occurs as sporadic cases and such contaminated food could be the source in some of these. This may be a rare event. On the other hand, given the frequent asymptomatic course of the disease, such a source may not be that uncommon since it may not be looked for in a patient with a normal convalescence.

1 Tabor E. The three viruses of non-A, non-B hepatitis. Lancet 1985 ;i: $743-5$

2 Bamber M, Thomas HC, Bannister B, Sherlock S. Acute type A, B, and non-A, non-B hepatitis in a hospital population in London: clinical and epidemiological features. Gut 1983;24:561-4

3 Caredda F, d'Arminio Monforte A, Rossi E, Lopez S, Moroni M. non-A, non-B hepatitis in Milan. Lancet $1981 ;$;i: 48.

4 Caredda F, Antinori S, Re T. Pastecchia C, Zavaglia C, Moroni M. Clinical features of sporadic non-A, non-B hepatitis possibly associated with faecal-oral spread. Lancet 1985;ii:444-5.

5 Caredda F, d'Arminio Monforte A, Rossi E, Zampini L, Lazzarin A, Moroni M. Prolonged course and relapses of acute type A hepatitis. Boll Ist Sieroter Milan 1984;63:34-6.

(Accepted 21 March 1986

Infectious Diseases Clinic, University of Milan, L Sacco Hospital, 20157 Milan, Italy

F CAREDDA, MD, clinical research assistant

$S$ ANTINORI, MD, resident

T RE, MD, resident

C PASTECCHIA, MD, resident

M MORONI, MD, director

Correspondence to: Dr Caredda. 